\title{
Prototype of IoT-Based Fruit Alcohol Level Measurement Tool
}

\author{
Nursila $^{1}$, Dirja Nur Ilham ${ }^{2 *}$, Amsar Yunan ${ }^{3}$, Muhammad Khoiruddin Harahap ${ }^{4}$, Rudi Arif Candra ${ }^{5}$ \\ 1,2,3,5 Politeknik Aceh Selatan, Indonesia, ${ }^{4}$ Politeknik Ganesha Medan, Indonesia \\ ${ }^{1}$ nurlalasyila@gmail.com, ${ }^{2}$ dirja.poltas@gmail.com, ${ }^{3}$ amsar.yunan@gmail.com, ${ }^{4}$ choir.harahap@yahoo.com, \\ ${ }^{5}$ rudiarifcandra@gmail.com
}

\begin{tabular}{|c|c|}
\hline $\begin{array}{l}\text { open } \\
\text { *Corresponding Author }\end{array}$ & $\begin{array}{l}\text { ABSTRACT } \\
\text { The effect of alcohol on health is very large if you consume too much, and the } \\
\text { fact that excessive alcohol levels can interfere with digestion can cause eye }\end{array}$ \\
\hline Article History: & function disorders, decreased brain and nerve function as well as cancer. Knowing \\
\hline Submitted: 09-02-2021 & the alcohol content in fruits that are suitable for consumption by the body from \\
\hline Accepted: 09-04-2021 & an early age is very important. Based on this problem, this study aims to create a \\
\hline Published: 09-04-2021 & prototype measuring instrument for the alcohol content of fruits using the Blynk \\
\hline $\begin{array}{l}\text { Keywords: } \\
\text { Sensors Mq3; Nodemcu; Blynk; } \\
\text { Fruits;Alcohol. }\end{array}$ & $\begin{array}{l}\text { application. This circuit consists of } 3 \text { circuits, namely the input part in the form } \\
\text { of an Mq } 3 \text { sensor, the control part in the form of Nodemcu, and the output port in } \\
\text { the form of the Blynk application. From the results of testing tools for four }\end{array}$ \\
\hline $\begin{array}{l}\text { Brilliance: International } \\
\text { Journal of Artificial } \\
\text { Intelligenceis licensed under a } \\
\text { Creative Commons Attribution- } \\
\text { NonCommercial } 4.0 \text { International } \\
\text { (CC BY-NC 4.0). }\end{array}$ & $\begin{array}{l}\text { samples including durian, grapes, papaya, and apples for } 25 \text { times the test of the } \\
\text { fruit is peeled for the next } 2 \text { hours the average percentage of durian alcohol } \\
\text { content is } 28.57 \% \text {, grapes are } 12.68 \% \text {, papaya is } 5.79 \% \text {, and apples by } 18.6 \% \text {. In } \\
\text { this study, there is also the notification facility to the third smartphone that the } \\
\text { alcohol content exceeds the alcohol content which is not good from the value set } \\
\text { on the device. }\end{array}$ \\
\hline
\end{tabular}

\section{INTRODUCTION}

Alcohol is a psychoactive substance that is addictive. Psychoactive substances are a class of substances that work selectively, especially on the brain that can cause changes in the perpetrator, cognitive emotions, perceptions, and awareness of a person. While addiction or addiction is an addiction or dependence on certain types of substances. A person who eats fruit in excess has a response range that fluctuates from mild to severe conditions, Alcohol is also a central nervous system depressant although in small amounts it may have a mild stimulatory effect (Tulung, 2015).

To determine the alcohol content in fruits can not be known directly, it is necessary to do testing in the laboratory. The tools used in laboratories generally have dimensions that are quite large and are expensive. Therefore, it is necessary to design a tool that can be used to determine alcohol content with small dimensions, relatively cheap prices, and easy and portable use. And from previous studies that discuss alcohol detection, there are already several of them detecting alcohol levels by (Pratama \& Jatmika, 2005)(Ismail, Marwanto, \& Haddin, 2021)(Surya Merta, Widagda, \& Alit Paramarta, 2017). Alcohol Level Detection System In The Human Body With Arduino Based MQ-3 Sensor by(Didik \& Hadi, 2019). Design of Alcohol Percent Detection Devices for Food Based on Arduino Uno (Anugreni et al., 2020). Measuring Tools of Alcohol Levels in Microcontroller-Based Solutions (Hasanah \& Latiffani, 2020). Design and Build of Alcohol Detector in Alcoholic Beverages using MQ-3 Sensor Based on ATmega328 (Made Pande Yudi Adnyana, Swamardika, \& Rahardjo, 2015)(Septian Syahputra, Fardhan Arkan, 2018). The application of the internet of things has also been widely carried out by previous researchers including The Infusion of Notification Design With an Application of Social Media Based on an Internet of Things (Candra, Saputra, Ilham, Setiawan, \& Hardisal, 2020). Rain monitoring system for nutmeg drying base on the internet of things (Ilham, Satria, Anugreni, Candra, \& Kusumo, 2021). Design of an Automatic Water Pump on a Traditional Boat (Ihsan, Ilham, Candra, Yunan, \& Hardisal, 2020). Heart Rate Monitoring and Stimulation with the Internet of Thing-Based (IoT) Quran Recitation (Ilham, Hardisal, Balkhaya, Candra, \& Sipahutar, 2019). Light Control Design by Using Social Media Telegram Applications Based on Internet Of Things (IoT) (Candra, Ilham, Hardisal, \& Sriwahyuni, 2019). Designing an Arduino-based Automatic Cocoa Fermentation Tool (Ilham, Balkhaya, Candra, Hardisal, \& Hasbaini, 2020).

Design and Build of an Arduino-Based Device for Detecting Alcohol Content in Car Driver's Breath (9). Based on the above background, this research will create a prototype measuring instrument for the alcohol content of fruits using the blynk application.

\section{LITERATURE REVIEW}

Many previous studies have measured and detected the value of alcohol content with different case studies and different samples, including the Design of Alcohol Level Detection Devices Through Exhalation Using the TGS2620 Sensor Based on the Arduino UNO Microcontroller (Tulung, 2015). Alcohol Level Detection System In The Human Body With Arduino Based MQ-3 Sensor (Didik \& Hadi, 2019). Design of Alcohol Percent Detection Devices for Food Based 
on Arduino Uno (Anugreni et al., 2020). Detection of Alcohol Levels Using a Website-Based MQ3 Sensor (Ismail et al., 2021). Measuring Tools of Alcohol Levels in Microcontroller-Based Solution (Hasanah \& Latiffani, 2020). Design and Build of Alcohol Level Detector in Alcoholic Drinks using Mq-3 Sensor (Septian Syahputra, Fardhan Arkan, 2018) (Made Pande Yudi Adnyana et al., 2015). Design and Build of an Arduino-Based Car Driver's Breath of Alcohol Content Detection (Triprasetyo, 2018).

\section{Tool Specifications}

\section{METHOD}

In designing this tool will discuss the needs that must be met, so that this tool can work according to what was planned, namely:

a. Using the MQ-3 Sensor which can work with a voltage of 3.3-5 volts to detect the alcohol content in fruits.

b. Nodemcu can be turned on with a supply voltage of 3.3 Volts, either using batteries or an adapter that is used as a control device.

c. The blynk application as a media controller or monitoring from a smartphone-based on the internet of things

The tools and materials we use in making prototypes for measuring the alcohol content of fruits with the blynk application include:

\section{Hardware}

The hardware used includes:

Table 1. Hardware and Specifications

\begin{tabular}{|c|c|c|}
\hline Number & Hardware & Specification \\
\hline 1 & Nodemcu & Amica Version 3 \\
\hline 2 & Sensor Mq-3 & $3,3-5$ Volt \\
\hline 3 & Breadboard & Mini \\
\hline 4 & Jumper Cable & Male to Female \\
\hline 5 & Adapter & $9-12$ volt \\
\hline
\end{tabular}

\section{Software}

The software used in this research are:

Table 2. Software and Specifications

\begin{tabular}{|c|c|c|}
\hline Number & Software & Specification \\
\hline 1 & Blynk & 2.27 .15 \\
\hline 2 & Arduino IDE & 1.8 .5 \\
\hline 3 & Fritzing & $0.9 .2 \mathrm{~b}$ \\
\hline
\end{tabular}

\section{Schematic Design / Block diagram}

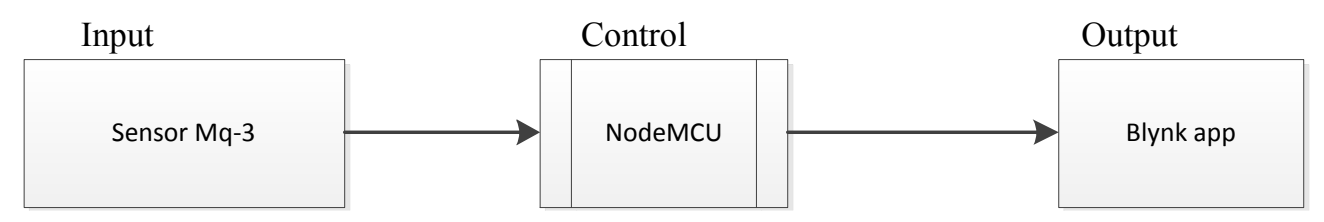

Figure 1. Block Diagram

\section{Information:}

1. Input Section

The input section consists of the MQ-3 Sensor which functions as a sensor to detect the alcohol content in the fruit.

2. Control Section

The control section consists of Nodemcu which functions as a controller of the entire circuit so that the circuit can work optimally.

\section{Output Section}

The output section consists of the Blynk Application which functions to display data on the results of alcohol levels detected by sensors via smartphones.

\section{Design Tools}


Design of Internet of Things-Based Measuring Tool for Alcohol Content in Fruits:

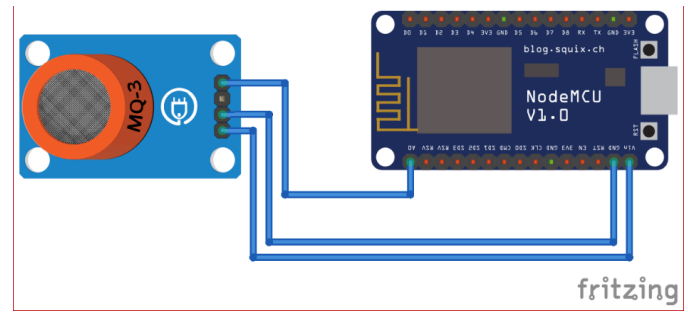

Figure 2. Tool Design

\section{Tool Sketch}

Information:

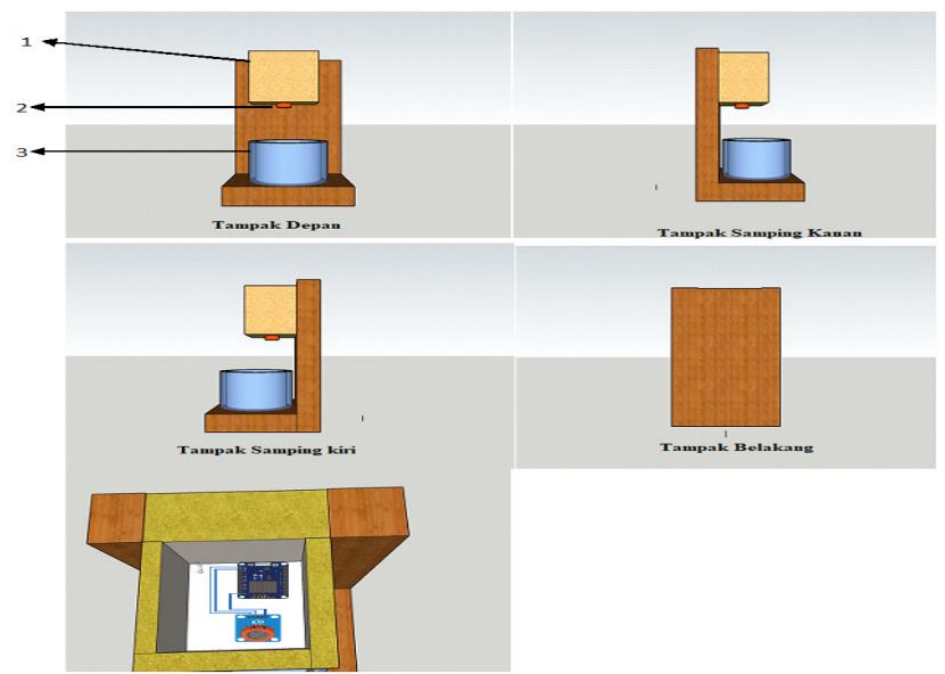

Figure 3. Sketch Tool

1. Tool storage box

2. Mq-3 Sensor as a Detector of Alcohol in Fruits

3. Plate for putting fruit

\section{Tool Working Principle}

The working principle of the Alcohol Content Measurement Tool in Fruits Using the Internet of Things-Based Blynk Application is if the sensor detects the presence of alcohol content in the fruit, the nodeMCU controls the entire series in the form of PPM data which will be processed to be displayed in the blynk application using the internet network.

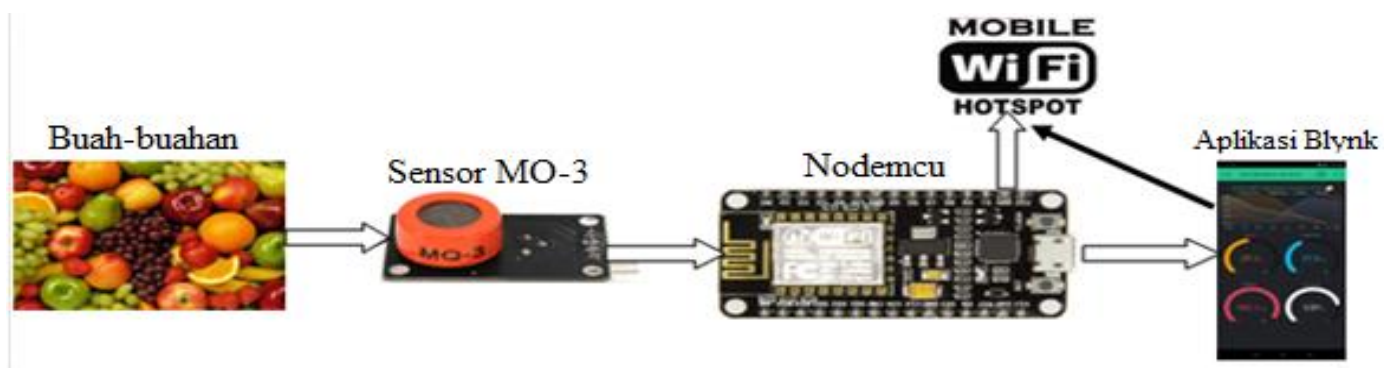

Figure 4. The Working Principle of the Tool

\section{System flowchart}

The following is a flowchart of the Internet of Things-Based Internet of Things Measuring Tool for Alcohol Content in Fruit. 


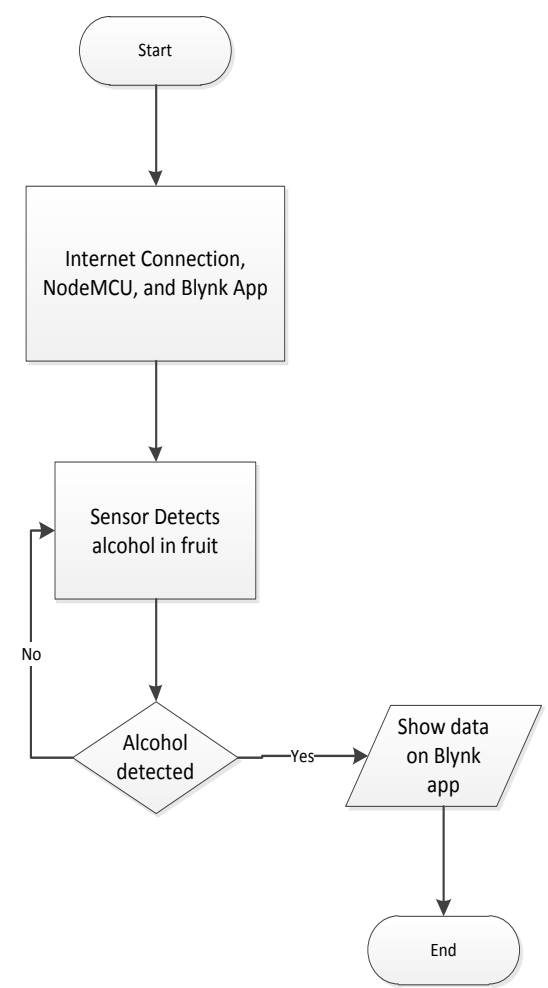

Figure 5. Flowchart of Program Flow

The flowchart above explains the flow of how the program:

The Blynk and Nodemcu applications must be connected to the internet so that NodeMCU can send data from near and far. The Mq-3 Sensor will work automatically if it detects alcohol in the fruit placed in front of it and will process the data sent from the sensor to be sent to the application. user interface or monitoring results that will be displayed in the form of graphs and PPM in the blynk application.

\section{Hardware implementation}

\section{RESULT}

The hardware implementation for making this fruit alcohol content measurement tool uses one Mq-3 sensor, NodeMCU, Breadboard, and, Adapter while the output directly to a smartphone uses the blynk application for displaying values and graphs.

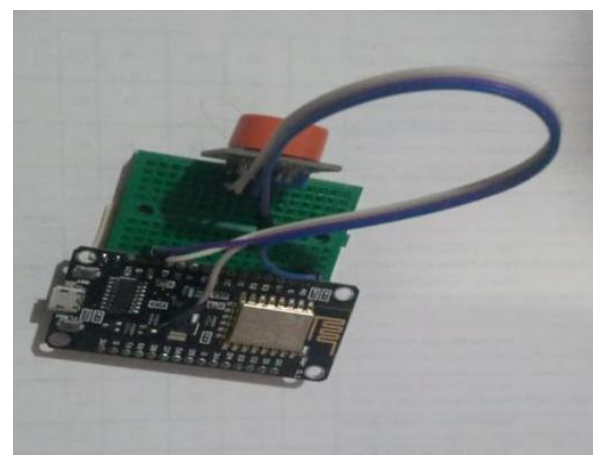

Figure 6. The whole set of tools

\section{Tool test results}

After the design of the tool was completed, testing was carried out on several fruits that were sampled including grapes, durians, apples, and young papayas. in the testing process, 25 times for each sample starting from the time the fruit was split until the next 2 hours so that the percentage of alcohol content contained in the four types of samples was as follows:

Table 3. Alcohol Level Test 
Volume 1, Number 1, February 2021

\begin{tabular}{|c|c|c|c|c|c|}
\hline Test & $\begin{array}{c}\text { Sensor reading } \\
\text { duration }\end{array}$ & Durian & Grapes & Papaya & Apple \\
\hline 1. & 1 to 12 seconds & $26.6 \%$ & $6.1 \%$ & $0 \%$ & $0 \%$ \\
\hline 2. & 1 to 10 seconds & $35.5 \%$ & $14 \%$ & $0 \%$ & $0 \%$ \\
\hline 3. & 2 to 9 seconds & $34.3 \%$ & $15 \%$ & $0 \%$ & $0 \%$ \\
\hline 4. & 1 to 9 seconds & $33.5 \%$ & $16.2 \%$ & $0 \%$ & $0 \%$ \\
\hline 5. & 2 to 10 seconds & $33.1 \%$ & $17.9 \%$ & $0 \%$ & $0 \%$ \\
\hline 6. & 2 to 14 seconds & $18.6 \%$ & $12 \%$ & $0 \%$ & $0 \%$ \\
\hline 7. & 1 to 9 seconds & $30.9 \%$ & $2.3 \%$ & $0 \%$ & $0 \%$ \\
\hline 8. & 2 to 16 seconds & $24 \%$ & $4.2 \%$ & $0 \%$ & $0 \%$ \\
\hline 9. & 2 to 15 seconds & $14.2 \%$ & $4.4 \%$ & $0 \%$ & $0 \%$ \\
\hline 10. & 2 to 11 seconds & $18.2 \%$ & $5.1 \%$ & $0 \%$ & $0 \%$ \\
\hline 11. & 1 to 11 seconds & $40.1 \%$ & $17.3 \%$ & $0 \%$ & $0 \%$ \\
\hline 12. & 2 to 13 seconds & $15.8 \%$ & $16.6 \%$ & $0 \%$ & $0 \%$ \\
\hline 13. & 1 to 10 seconds & $37.8 \%$ & $15 \%$ & $0 \%$ & $0 \%$ \\
\hline 14. & 2 to 13 seconds & $38.8 \%$ & $13 \%$ & $20.1 \%$ & $5.1 \%$ \\
\hline 15. & 1 to 11 seconds & $10.5 \%$ & $10.3 \%$ & $2.3 \%$ & $17.1 \%$ \\
\hline 16. & 2 to 9 seconds & $33 \%$ & $14.9 \%$ & $2.9 \%$ & $10.2 \%$ \\
\hline 17. & 2 to 11 seconds & $13 \%$ & $13.7 \%$ & $17.9 \%$ & $14.2 \%$ \\
\hline 18. & 2 to 8 seconds & $56 \%$ & $16.5 \%$ & $9.8 \%$ & $15.2 \%$ \\
\hline 19. & 1 to 11 seconds & $19.5 \%$ & $17.5 \%$ & $3.5 \%$ & $9.5 \%$ \\
\hline 20. & 2 to 8 seconds & $52 \%$ & $14.7 \%$ & $19.1 \%$ & $12.5 \%$ \\
\hline 21. & 1 to 11 seconds & $20.5 \%$ & $13.3 \%$ & $6.5 \%$ & $11.5 \%$ \\
\hline 22. & 2 to 14 seconds & $20.1 \%$ & $12.4 \%$ & $3.5 \%$ & $14.5 \%$ \\
\hline 23. & 2 to 10 seconds & $22.5 \%$ & $14.1 \%$ & $16.5 \%$ & $16.8 \%$ \\
\hline 24. & 2 to 9 seconds & $15 \%$ & $15.5 \%$ & $20.1 \%$ & $10.8 \%$ \\
\hline 25. & 2 to 12 seconds & $48.7 \%$ & $14.7 \%$ & $2.5 \%$ & $12.8 \%$ \\
\hline & Average & $28.57 \%$ & $12.68 \%$ & $5.79 \%$ & $18.6 \%$ \\
\hline
\end{tabular}

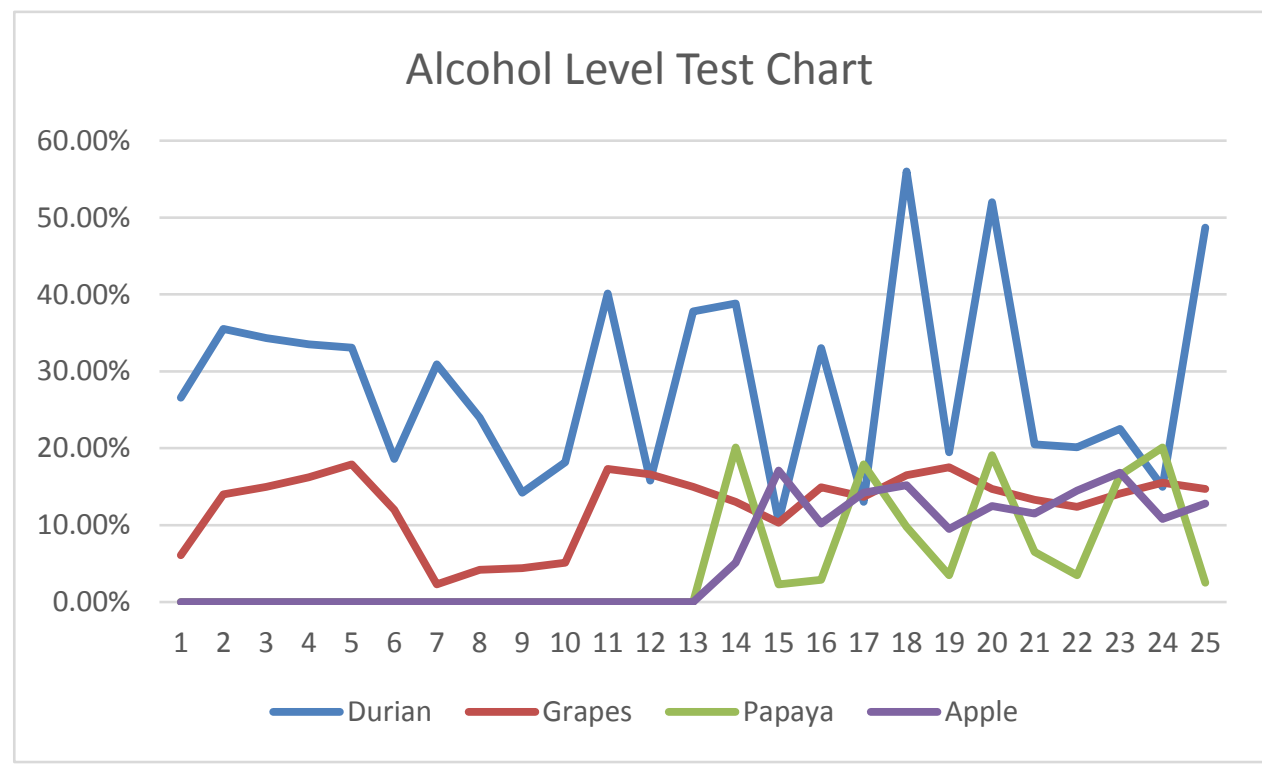

Figure 7. Graph of test results

Tests were carried out on each fruit, namely durian, grapes, papaya, and apples. Each fruit that has been tested contains different levels of alcohol, but the duration of the sensor reading or the level of sensitivity of the sensor in reading the alcohol content of the fruit is about 1 to 2 seconds, and the sensor reading time to get the maximum results from the fruit. -fruits which is about 8 to 15 seconds. Where the purpose of the reading is the length of the calculation of the alcohol content reading on the fruit from 0 to get the maximum result if the fruit does not contain alcohol then the detected fruit is only brought near for 8 seconds and the results read are still 0 means the fruit does not contain alcohol. 


\section{DISCUSSION}

Tests for measuring the alcohol content of fruits were carried out with 4 types of samples, namely durian, grapes, papaya, and apples as many as 25 times for each sample. from the test results it is known that the duration of the sensor to detect alcohol levels is on average 8 to 15 seconds.

\section{CONCLUSION}

The alcohol level detector made can detect the alcohol content of the four samples used and from the average value of the alcohol content of each sample by testing 25 times for each sample, it is found that durian and grapes are the fruits with the highest alcohol content.

\section{REFERENCES}

Anugreni, F., Candra, R. A., Ben, H., Hardisal, Adami, F., \& Syam, I. (2020). Design of Alcohol Percent Detection Devices for Food Based on Arduino Uno. Jurnal Inotera, 5(2), $113-119$. https://doi.org/10.31572/inotera.vol5.iss2.2020.id118

Candra, R. A., Ilham, D. N., Hardisal, H., \& Sriwahyuni, S. (2019). Light Control Design by Using Social Media Telegram Applications Based on Internet Of Things (IOT). SinkrOn, 3(2), 200. https://doi.org/10.33395/sinkron.v3i2.10094

Candra, R. A., Saputra, D. S., Ilham, D. N., Setiawan, H., \& Hardisal, H. (2020). The Infusion of Notification Design With an Application of Social Media Based on a Internet of Things (IOT). SinkrOn, 5(1), 129. https://doi.org/10.33395/sinkron.v5i1.10610

Didik, W., \& Hadi, A. P. (2019). Jurnal PIXEL diterbitkan oleh Sekolah Tinggi Elektronika dan Komputer (STEKOM). Jurnal PIXEL sebagai sarana komunikasi dan penyebarluasan hasil penelitian, pemikiran serta pengabdian pada masyarakat. Sistem Informarsi Akademi Dengan RFID Berbasis Sms Gateway (Studi Kasus Di Smk Muhhammadiyah 2 Boja), 12(1), 1-35.

Hasanah, U., \& Latiffani, C. (2020). International Conference on Social, Sciences and Information Technology. 4509(1), $1-7$.

Ihsan, I., Ilham, D. N., Candra, R. A., Yunan, A., \& Hardisal, H. (2020). Design of an Automatic Water Pump on a Traditional Boat. SinkrOn, 5(1), 100. https://doi.org/10.33395/sinkron.v5i1.10635

Ilham, D. N., Balkhaya, B., Candra, R. A., Hardisal, H., \& Hasbaini, H. (2020). Designing an Arduino-based Automatic Cocoa Fermentation Tool. SinkrOn, 5(1), 92-99. https://doi.org/10.33395/sinkron.v5i1.10611

Ilham, D. N., Hardisal, H., Balkhaya, B., Candra, R. A., \& Sipahutar, E. (2019). Heart Rate Monitoring and Stimulation with the Internet of Thing-Based (IoT) Alquran Recitation. SinkrOn, 4(1), 221. https://doi.org/10.33395/sinkron.v4i1.10392

Ilham, D. N., Satria, E., Anugreni, F., Candra, R. A., \& Kusumo, H. N. R. A. (2021). Rain Monitoring System for Nutmeg Drying Based on Internet of Things. Journal of Computer Networks, Architecture, and High-Performance Computing, 3(1), 52-57. https://doi.org/10.47709/cnahpc.v3i1.933

Ismail, M., Marwanto, A., \& Haddin, M. (2021). Deteksi Kadar Alkohol Menggunakan Sensor MQ3 Berbasis Website. Infotekmesin, 12(1), 88-92. https://doi.org/10.35970/infotekmesin.v12i1.490

Made Pande Yudi Adnyana, A., Swamardika, I. B. A., \& Rahardjo, P. (2015). RANCANG BANGUN ALAT PENDETEKSI KADAR ALKOHOL PADA MINUMAN BERALKOHOL MENGGUNAKAN SENSOR MQ-3 BERBASIS ATmega328 Pande. Jurnal Sensor MQ-3, 2(3), 111-116.

Pratama, \& Jatmika. (2005). Pendeteksi kadar alkohol. Jurnal Teknik Komputer, 39(9), 123-131.

Septian Syahputra, Fardhan Arkan, R. F. G. (2018). a a. a-R. Rancang Bangun Alat Pendeteksi Kadar Alkohol Pada Produk Minuman Berbasis Arduino, 72-75.

Surya Merta, I. G., Widagda, I. G. A., \& Alit Paramarta, I. B. (2017). Perancangan Alat Ukur Kadar Alkohol Menggunakan Sensor Mq-3 Berbasis Mikrokontroler Atmega16. Buletin Fisika, 18(2), 74. https://doi.org/10.24843/bf.2017.v18.i02.p06

Triprasetyo, Y. (2018). Tugas Akhir, Jurusan Teknik Elektro Fakultas Teknik, Universitas Semarang. Rancang Bangun Alat Pendeteksi Kadar Kandungan Alkohol Pada Nafas Pengendari Mobil Berbasis Arduino, (21), 1-9.

Tulung, N. M. (2015). Rancang Bangun Alat Pendeteksi Kadar Alkohol Melalui Ekhalasi Menggunakan Sensor Tgs2620 Berbasis Mikrokontroler Arduino Uno. Jurnal Teknik Elektro Dan Komputer, 4(7), 15-24. 